Олійник Володимир Вікторович доктор наук з державного управління, доцент кафедри публічного управління та менеджменту інноваційної діяльності Навчально-наукового інституту неперервної освіти i туризму, Національного університету біоресурсів і природокористування України, вул. Героїв Оборони, 11, м. Київ, 03041, тел.: (044) 527-86-35, e-mail: oliynyk-v-v@ukr.net, https://orcid.org/0000-0002-4647-2658

\title{
ЗАБЕЗПЕЧЕННЯ ІНФОРМАЦИЙНОЇ ВІДКРИТОСТІ ТА ПРОЗОРОСТІ УПРАВЛІННЯ ПЕРСОНАЛОМ В ОРГАНАХ ПУБЛІЧНОЇ ВЛАДИ
}

Анотація. У статті досліджено питання відкритості та прозорості управління в органах публічної влади. Виокремлено головні характеристики відкритості до яких віднесено забезпечення: прав людини відповідно до норм законодавства; участі у державних справах; дотримання вимог нормативно-правових актів посадовими особами; забезпечення гласності затвердження управлінських рішень; інформування громадян про діяльність органів публічної влади.

На підставі аналізу наукових праць 3'ясовано, що основною підставою для ефективності публічної влади, сформованої демократичним шляхом, є відкритість, оскільки відсутність відкритості не дозволяє ефективно використовувати такий демократичний механізм контролю за діяльністю органів публічної влади як суспільний контроль. Встановлено, що відкритість визначається як стан об'єкта, що характеризується його доступністю і може мати дуалістичне значення: як якісна ознака управління персоналом і як принцип функціонування органу влади / структурного підрозділу / публічного службовця.

3'ясовано ключову роль інформаційної відкритості та прозорості в публічному управлінні, яка полягає в підвищенні результативності прийняття управлінських рішень і підтриманні соціальної стабільності шляхом надання доступності до процесу ухвалення управлінських рішень та інформаційної відкритості діяльності всіх елементів системи публічного управління.

Виокремлено види відкритості в державній службі, серед яких: інформаційна відкритість, спрямована на надання населенню об'єктивної, точної та повної інформації про діяльність органів публічної влади, законодавство, послуги, права та обов'язки громадян; кар'єрна відкритість, спрямована на забезпечення вільного доступу до публічної служби, заміщення вакантних посад в органах державної влади на основі врахування професійних та особистих якостей кандидатів; персональна відкритість публічних службовців, яка проявляється через здатність службовців нести відповідальність за свою професійну діяльність; сервісну відповідальність, що спрямована на якісне надання адміністративних послуг громадянам органами та посадовими особами.

Ключові слова: інформаційна відкритість, органи публічної влади, державна служба, служба персоналу. 
Oliinyk Volodymyr Viktorovych Doctor of Science in Public Administration, Associate Professor of the Department of Public Administration and Innovation Management Educational and Scientific Institute of Continuing Education and Tourism, National University of Life and Environmental Sciences of Ukraine, Heroiv Oborony str., 11, Kyiv, 03041, tel.: (044) 527-86-35, e-mail: oliynyk-v-v@ukr.net https://orcid.org/0000-0002-4647-2658

\section{ENSURING INFORMATION OPENNESS AND TRANSPARENCY OF PERSONNEL MANAGEMENT IN PUBLIC AUTHORITIES}

Abstract. The article examines issues of openness and transparency of management in public authorities. The main parameters of openness are highlighted, which include the provision of: human rights in accordance with the legislation; participation in public affairs; compliance with the requirements of regulatory legal acts by officials; ensuring the publicity of the approval of management decisions; informing citizens about the activities of public authorities.

Based on the analysis of scientific works, it has been established that the main basis for the effectiveness of public power, formed by a democratic way, is openness, since the lack of openness does not allow effective use of such a democratic mechanism of control over the activities of public authorities as public control. It has been established that openness is defined as the state of an object characterized by its accessibility and can have a dualistic meaning: as a qualitative feature of personnel management and as a principle of functioning of a government body /structural unit/ public servant.

The key role of information openness and transparency in public administration has been clarified, which consists in increasing the effectiveness of management decisionmaking and maintaining social stability by providing accessibility to the management decision-making process and information transparency of the activities of all elements of the public administration system.

There are types of openness in the civil service, including: information openness aimed at providing the population with objective, accurate and complete information about the activities of public authorities, legislation, services, rights and responsibilities of citizens; career openness aimed at ensuring free access to public service, filling vacancies in public authorities on the basis of taking into account the professional and personal qualities of candidates; personal openness of public servants, which is manifested through the ability of employees to be responsible for their professional activities; service responsibility aimed at providing quality administrative services to citizens by bodies and officials.

Keywords: information openness, public authorities, civil service, personnel service.

Постановка проблеми. Втілення демократичних принципів управління персоналом в органах публічної влади має відбуватись відповідно до концептуального розуміння його відкритості. Це поняття мало б активно використовуватися у законодавстві та науковому дискурсі. В умовах 
реформування державної служби виникає потреба змістового обгрунтування «відкритості державної служби», окреслення проблеми забезпечення їі відкритості. Це потребує напрацювання теоретичного обгрунтування до висвітлення поняття «відкритість державної служби», а також формулювання типових ознак їі видів, головних характеристик відкритості, зокрема: забезпечення прав людини відповідно до норм законодавства; іiі участі державних справах; дотримання вимог нормативно-правових актів посадовими особами; забезпечення гласності затвердження управлінських рішень, інформування громадян про діяльність органів публічної влади. Разом з тим відкритість та прозорість управління дає можливість досягти стабільності в соціумі, підвищує результативність прийняття управлінських рішень.

Аналіз останніх досліджень і публікацій. Проблематиці забезпечення відкритості державної служби присвячені публікації таких вітчизняних дослідників, як В. Авер'янов, Е. Афонін, Н. Гудима, О. Крет, Н.Нижник, B. Пилаєва, В.М. Ярошенко та інших. Аналізуючи праці науковців, спостерігається усвідомлення значущості принципу відкритості, на якому має базуватися ефективна діяльність органів публічної влади. Водночас, саме поняття відкритості, параметри та детермінанти якості відкритості, які часто поєднують 3 іншими характерними ознаками управління персоналом в органах публічної влади, залишаються малодослідженими. Відкритість цього процесу є характеристикою професійної діяльності, а тому досить важко відстежити, як вона забезпечується на практиці. Метою даного дослідження є пошуки ефективних шляхів вирішення цих актуальних питань.

ННІ неперервної освіти і туризму Національного університету біоресурсів i природокористування України, що здійснюються у межах науково-дослідної теми "Теоретичні засади і механізми реалізації інноваційних процесів у публічному управлінні” (ДР №118U100146).

Мета статті - конкретизація та деталізація інформаційної відкритості та виокремленні їі видів в управлінні персоналом органів публічної влади.

Відповідно до мети статті визначено такі завдання:

1) уточнити змістовне навантаження поняття «відкритості» як демократичного принципу діяльності органів публічного управління;

2) з'ясувати способи підвищення рівня відкритості в управлінні персоналом;

3) запропонувати деякі заходи щодо динамічного впровадження відкритості в управлінні персоналом 3 метою підвищення його соціальної спрямованості та ефективності.

Виклад основного матеріалу. в органах публічної влади відкритість може виступати і певною якісною ознакою управління персоналом, так і відповідним принципом його функціонування. Відкритість визначається як стан об'єкта, що характеризується доступністю його.

Управління персоналом в органах публічної влади - це непростий процес i багатогранний. Від того, наскільки ефективно впроваджуються та працюють різноманітні технології та принципи управління персоналом, залежить ефективність та результативність державних службовців та посадових осіб місцевого самоврядування. 
Часто на міжнародному рівні принцип відкритості ототожнюється із принципом прозорості, що пов'язано 3 етимологічним походженням двох зазначених категорій, хоча в Україні науковці стараються розрізняти відкритість від прозорості й наводять відповідну аргументацію. Деталізація «відкритості» призводить до того, що такий принцип може поєднуватись не тільки із прозорістю, але й із гласністю чи доступністю органів публічної влади. Зокрема, це стосується таких понять, як: «відкритість інформації» (сполучено із прозорістю), «відкритість органу публічної влади щодо прийняття управлінських рішень» (сполучено із доступністю), «відкритість адміністративного процесу» (сполучено з гласністю). Проведемо більш детальний аналіз зазначених категорій.

Основною підставою для ефективності публічної влади, сформованої демократичним шляхом, $є$ відкритість. Коли відкритість відсутня, суспільний контроль за діями влади є неможливим. Лише в тому випадку, якщо публічна влада «прозора», тобто відкрита, надає про свої рішення та дії повну і точну інформацію, правдива у своїх намірах, тоді можна визначити, наскільки іiі дії відповідають закону та є моральними [1].

У науковій літературі часто використовують категорію «інформаційна відкритість», яку можна трактувати так само як і прозорість органу публічної влади. Так, інформаційна відкритість полягає у створенні відповідних інформаційних каналів від органів державної влади до громадян, через які населення матиме змогу отримувати важливу, правдиву та детальну інформацію [2, с. 92]. Водночас, прозорість органів влади реалізується через: обов'язки розпорядників інформації надавати та оприлюднювати інформацію, крім випадків, передбачених законом; організацію доступу до публічної інформації визначеним розпорядником відповідальним підрозділом чи посадовою особою; максимальне спрощення процедури подання запиту та отримання інформації; здійснення парламентського, громадського (у т. ч. шляхом проведення громадських експертиз) та державного контролю за дотриманням прав на доступ до публічної інформації [3, с. 163]. Можемо констатувати, що в інформаційному контексті відкритість можна трактувати так само як і прозорість, однак даний критерій $\epsilon$ значно ширшим від неї.

Так, прозорість надає можливість громадянам одержати необхідну та точну інформацію про функціонування органів влади, а відкритість дозволяє брати активну участь, впливати на прийняття рішень та розроблення й впровадження державних програм розвитку. Основна відмінність між відкритістю та прозорістю у тому, що перша носить активний характер, тобто передбачає певні дії громадян, а друга - є скоріше пасивним станом, за якого населення лише має можливість одержувати потрібну інформацію про діяльність органів влади.

У Статті 4 Закону України «Про державну службу» задекларовано прозорість - відкритість інформації про діяльність державного службовця, як один принципів з дотриманням якого здійснюється державна служба [4].

Варто зазначити, що в Україні принцип прозорості влади $є$ одним із першочергових у діяльності органів публічної влади. Зауважимо, що Законом України «Про доступ до публічної інформації» передбачено три загальні принципи забезпечення доступу до публічної інформації: 
1) прозорості та відкритості діяльності суб’єктів владних повноважень;

2) вільного отримання та поширення інформації, крім обмежень, установлених законом;

3) рівноправності, незалежно від ознак раси, політичних, релігійних та інших переконань, статі, етнічного та соціального походження, майнового стану, місця проживання, мовних або інших ознак [5, с. 242].

Н. Гудима розмежовує поняття відкритість i прозорість, розглядає їх як принципи функціонування органів публічного управління, при цьому відкритість державної влади визначає як обов'язок із забезпечення можливості вільного доступу громадян до здійснення управління державними справами, а прозорість у встановленні органами публічного управління умов, що забезпечують залучення громадян та інших об’єктів управління до прийняття управлінських рішень за рахунок створення і гарантування високого рівня їх обізнаності [6, с. 16].

Відкритість передбачає наявність у системі правових відносин широких каналів взаємопроникнення для всього спектра соціальних, економічних i політичних сил. Таким чином, принцип відкритості забезпечує можливості вільного доступу громадян до здійснення управління державними справами безпосередньо, наприклад на посадах державних службовців, або опосередковано, шляхом участі в демократичних виборах [7].

Якщо відкритість дає можливість особі спостерігати або брати участь у діяльності органу публічної влади, то прозорість слід відносити до можливості особи зрозуміти, як саме працює механізм публічного управління, як відбувається процес реалізації, наприклад, місцевою державною адміністрацією іiі завдань. Відкритість носить соціально-комунікативний характер, а прозорість - виключно функціональний, завдяки чому вона спрямована на оптимізацію регулятивних процесів у системі публічного управління. Таким чином, значення поняття прозорості найчастіше пов'язано 3 інформаційною відкритістю соціальних, економічних і політичних процесів.

На сьогодні у вітчизняній науковій літературі поширеним став також термін «транспарентність», що 3 англійської мови перекладається як прозорість. Однак значення транспарентності часто пов’язують із відкритістю, а саме iз інформаційним забезпеченням соціальних, економічних та політичних процесів. Транспарентність може відображати вплив інформації, що передбачає двосторонній взаємозв'язок між державою та громадянським суспільством: «зверху» - через забезпечення відкритості державної влади перед громадянами та надання їм відповідної інформації; - «знизу» - як зворотній зв’язок, шляхом забезпечення рівних можливостей для участі громадян у політичному житті.

Американський вчений К. Худ стверджує, що термін «транспарентність»у відношенні до публічного управління вперше вжитий відомим філософом i правознавцем Дж. Бентамом у 1790-х рр. у контексті прозорого управління або гласності (transparent-management or publicity) [8, с. 10]. Проте, 3 того часу проблема транспарентності фактично не піднімалася до 1980-х рр., коли у світі розпочався процес правової регламентації положень щодо забезпечення свободи слова, доступу до ухвалення державних рішень, розповсюдження інформації 
органами влади, що знайшло відображення у прийнятих нормативноправових актах низки країн.

За дослідженням Е. Афоніна, у транспарентних відносинах відкритість, прозорість та гласність є органічно поєднані, проте самі по собі ці принципи державної служби не тотожні між собою, а тільки доповнюють один одного, оскільки забезпечення ефективного управління можливе, коли за рахунок прозорості громадяни можуть бачити всі проблеми та недоліки на державній службі, а відкритості - впливати на їх усунення [9, с. 9]. На думку автора, поняття «відкритість», «прозорість» та «гласність» є певними атрибутивними ознаками транспарентності. Такої ж думки дотримується Є. Романенко, який під основними рівнями транспарентності публічного управління розуміє поняття гласності, відкритості та публічності, вкладаючи в них законодавчий та доктринальний зміст. При цьому, гласність розглядається як: доступність для громадського ознайомлення; загальновідомість будь-чого, оголошення; відкритість характеризує доступність для всіх бажаючих, щирість, незакритість істини; а публічність реалізація будь-якої діяльності у присутності публіки, щось суспільне, а не приватне [10, с. 19].

За твердженням О. Крет, саме термін «транспарентність» дає можливість комплексно розглянути проблему і розмежувати низку термінів, близьких, але не тотожних йому. Аналізуючи термін «транспарентність», автор застосовує підхід, який дозволяє визначити транспарентність державної влади як відкритість, прозорість, гласність, публічність і підзвітність процесу формування, розвитку та функціонування органів державної влади різного рівня та процесу прийняття ними рішень [11, с. 15].

Значення поняття «транспарентність» визначає поінформованість громадян 3 приводу прийняття політичних рішень, інформаційну відкритість соціальних, економічних та політичних процесів, транспарентність (прозорість) - це обізнаність діями влади, а відкритість - це реальна можливість вплинути на ііі зміст $[12$, с. 86]. Про те, що транспарентність у публічному управлінні стосується саме інформаційної відкритості органів державної влади, забезпечення ними комунікацій 3 громадськістю шляхом інформування та надання роз'яснення стосовно мети, напрямів та завдань, цілей, досягнень і недоліків своєї діяльності зазначає В. Пилаєва [13, с. 262].

Аналіз сучасних досліджень 3 теорії публічного управління, присвячених проблемі відкритості/закритості державної служби, засвідчив те, що категорія «відкритість» досліджується із «публічністю», «прозорістю», «доступністю», «транспарентністю», водночас досить часто ототожнюється, або як мінімум порівнюється $з$ ними. Однак, це не зовсім правильний підхід. На нашу думку, відкритість управління персоналом є більш ширшим критерієм функціонування органів публічної влади. Нерідко науковці відкритість державної служби пов'язують тільки 3 інформуванням громадян щодо діяльності органів державної влади та їх залученням до прийняття управлінських рішень, однак, це є не зовсім коректним у питанні практичного втілення відкритості державної служби як важливого атрибуту та характеристики цієї професійної діяльності. 
В органах публічної влади принципи відкритості та прозорості задекларовані в нормативно-правових актах, наприклад, у Кодексі етики державних службовців (посадових осіб місцевого самоврядування).

Видається вартою уваги думка I. Грищенко, що «керівники громад, які $\epsilon$ ефективними менеджерами, тобто їх діяльність спрямована на постійне досягнення результатів у покращенні життєдіяльності громади, були обрані на цю посаду знову і врешті-решт покращили свою здатність спілкуватися та залучати громадськість до адміністрування, їхня потреба у владі стає більш соціально орієнтованою з певним часом» [14].

Поняття «відкритість державної служби» характеризує активно-діяльнісну природу державної служби, яка виявляється в багатьох аспектах її функціонування. Саме активно-діяльнісна природа державної служби $є$ підгрунтям для відокремлення поняття «відкритість» від понять «публічність», «доступність», «прозорість» та «транспарентність». Це дає змогу визначити окремі види відкритості державної служби:

- інформаційну (надання населенню об’єктивної, точної та повної інформації про діяльність органів державної влади, законодавство, послуги, права та обов'язки громадян);

- сервісну (урахування та задоволення потреб громадян відповідно до нормативної бази);

- кар'єрну (забезпечення вільного доступу до державної служби, заміщення вакантних посад в органах державної влади на основі врахування професійних та особистих якостей кандидатів);

- персональну відкритість державних службовців (здатність посадових осіб нести відповідальність за свою діяльність) [15].

Виходячи з вищесказаного можна констатувати, що якщо явище відкритості має соціально-комунікативний характер. Відкритість у публічному управлінні не просто відкриває суспільству доступ до управлінської інформації, вона за допомогою реалізації такого роду доступу принципово видозмінює в бік соціальної орієнтованості діяльність владних структур. Щоб даний процес здійснювався 3 максимальною ефективністю, необхідно дотримуватися низки певних принципів, зокрема:

- формування більш стрункої і менш заплутаної системи органів публічної влади управління із чітким визначенням їх компетенції і функцій;

- законодавче закріплення діалогу служби управління персоналом 3 громадськістю й фактичне гарантування доступності для суспільства інформації про їі діяльність;

- досягнення розумної відкритості всіх етапів процесу підготовки й реалізації державних рішень із життєвоважливих суспільно-політичних питань щодо управління персоналом в органах публічної влади.

Висновки. Отже, відкритість та прозорість $\epsilon$ різними критеріями в управлінні персоналом в органах публічної влади, оскільки перша носить активний характер, який характеризує можливість впливати громадян на прийняття управлінських рішень, а друга - скоріше пасивний характер, при якому громадяни скоріше отримують інформацію про діяльність відповідної служби. Відкритість фактично є 
ознакою участі громадян у діяльності органів державної влади; забезпечення активного суспільного контролю над реалізацією ними відповідних завдань i реального впливу громадян на управлінську діяльність, а транспарентність, як $\mathrm{i}$ прозорість має ті ж самі особливості.

На сучасному етапі реформування системи публічного управління в Україні стан законодавчої та нормативно-правової бази не забезпечує належної реалізації принципу відкритості. Виходячи 3 цього системні та комплексні дослідження $\epsilon$ актуальними та зумовлені необхідністю подальших демократичних перетворень у системі публічного управління.

\section{Лimepamypa:}

1. Грищенко I.М., Горбата Л. П. Пріоритетні напрями та иляхи забезпечення інформаційної відкритості в органах публічної влади. Public and municipal administration: theory, methodology, practice : Collective monograph. Riga : Izdevnieciba "Baltija Publishing", 2020. 324 p. C. 20-40. DOI: https://doi.org/10.30525/978-9934-588-46-4.02

http://baltijapublishing.lv/omp/index.php/bp/catalog/book/39

2. Крук Н. В. Інформаційна відкритість державної влади як інституційна гарантія основних принципів демократичної держави / Н. В. Крук // Політикус. - 2017. - Вип. 2. - С. 9194.

3. Куспляк I. С. Прозорість та відкритість влади: від концепту «прозорого міста» до порталу відкритих даних / І. С. Куспляк // Теоретичні та прикладні питання державотворення. 2015. - Вип. 16. - С. 159-171.

4. Про державну службу : Закон України від 16.12.1993 № 3723- XII : із зм. і доп. станом на 16.07.2020 // Відомості Верховної Ради України. URL: https://zakon.rada.gov.ua/laws/show/88919\#Техt (дата звернення 05.09.2020).

5. Заяць О.С. Перспективи розвитку права громадян на отримання інформації від органів державної влади в сучасних умовах державотворення // Наукові записки Львівського університету бізнесу та права : зб. наук. пр. 2013. №11. С. 241-245.

6. Гудима Н. В. Принципи відкритості і прозорості в діяльності органів державного управління України: автореф. дис. на здобуття наук. ступ. канд. наук з держ. упр.: спец. 25.00.01 «Теорія та історія державного управління» / Н. В. Гудима. - К.: 2008. - С. 20.

7. Гудима Н. Принципи відкритості і прозорості та їх реалізація в державному управлінні / Н. Гудима // Вісн. НАДУ. - 2005. - № 3. - С. 77-85.

8. Hood Ch. Transparency in historical perspective / Ch. Hood // Transparency: The Key to Better Governance. - Oxford: Oxford University Press, 2006. - P. 3-23.

9. Афонін Е. А. Транспарентність влади в контексті європейської інтеграції України: конспект лекцій до короткотермінового семінару в системі підвищення кваліфікації кадрів / Е. А. Афонін, О. В. Суший. - К.: НАДУ, 2010. - С. 48.

10. Романенко С. О. Відкритість та прозорість як структурні рівні транспарентності державного управління та їх комунікативні функції / С. Романенко // Теоретичні та прикладні питання державотворення: ел. наук. фах. вид. - 2014. - Вип. 14. - С. 17-31.

11. Крет О. В. Інституалізація транспарентності державної влади: автореф. дис. на здобуття наук. ступ. канд. політ. наук: спец. 23.00.02 «Політичні інститути та процеси» / О. В. Крет. - Чернівці: 2010. - С. 20.

12. Ярошенко В. М. Транспарентність та відкритість влади як механізми становлення інституту демократичної громадянськості / В. М. Ярошенко // Наукові праці Чорноморського державного університету імені Петра Могили. - 2012. - Вип. 170. - Т. 182. - С. 85-91. - (Серія: Політологія). 
13. Пилаєва В. М. Правові засади реалізації принципу транспарентності в діяльності органів виконавчої влади / В. М. Пилаєва // Вісник Харківського національного університету імені В. Н. Каразіна. - 2016. - Вип. 21. - С. 261-264. - (Серія: Право).

14. Gryshchenko I. The impact on the formation of personal needs leadership. Scientific Bulletin of National Mining University (SciVerse Scopus). 2016. Vol. 4\& pp. 154-160. http://nbuv.gov.ua/UJRN/Nvngu_2016_4_22.

15. Мосора Л. С. Відкритість як критерій оцінки якості функціонування державної служби / Л. С. Мосора // Молодий вчений. - 2018. - № 1(1). - С. 464-467. - Режим доступу: http://nbuv.gov.ua/UJRN/molv_2018_1\%281\%29_110

\section{References:}

1. Hryshchenko, I.M., Horbata, L.P. (2020). Priorytetni napriamy ta shliakhy zabezpechennia informatsiinoi vidkrytosti $\mathrm{v}$ orhanakh publichnoi vlady [Priority areas and ways to ensure information openness in public authorities]. Public and municipal administration: theory, methodology, practice. (pp. 20-40). Riga: Izdevnieciba "Baltija Publishing". DOI: https://doi.org/10.30525/978-9934588-46-4.02. Retrieved from http://baltijapublishing.lv/omp/index.php/bp/catalog/book/39 [in Ukrainian].

2. Kruk, N.V. (2017). Informatsiina vidkrytist derzhavnoi vlady yak instytutsiina harantiia osnovnykh pryntsypiv demokratychnoi derzhavy [Information openness of state power as an institutional guarantee of the basic principles of a democratic state]. Politykus - Politicus, 2, 91-94 [in Ukrainian].

3. Kuspliak, I.S. (2015). Prozorist ta vidkrytist vlady: vid kontseptu «prozoroho mista» do portalu vidkrytykh danykh [Transparency and openness of power: from the concept of "transparent city" to the portal of open data]. Teoretychni ta prykladni pytannia derzhavotvorennia - Theoretical and applied issues of state formation, 16, 159-171 [in Ukrainian].

4. Zakon Ukrainy "Pro derzhavnu sluzhbu" : vid 16 hrudnia 1993 № 3723-XII [Law of Ukraine "On civil service" from December 16, 1993 № 3723-XII]. Vidomosti Verkhovnoi Rady Ukrainyn Bulletin of Verkhovna Rada of Ukraine, 4. Art. 43. Retrieved from https://zakon.rada.gov.ua/laws/show/889-19\#Text [in Ukrainian].

5. Zaiats, O.Ye. (2013). Perspektyvy rozvytku prava hromadian na otrymannia informatsii vid orhaniv derzhavnoi vlady v suchasnykh umovakh derzhavotvorennia [Prospects for the development of the right of citizens to receive information from public authorities in modern conditions of state formation]. Naukovi zapysky Lvivskoho universytetu biznesu ta prava - Scientific Notes of Lviv University of Business and Law, 11, 241-245 [in Ukrainian].

6. Hudyma, N.V. (2008). Pryntsypy vidkrytosti i prozorosti v diialnosti orhaniv derzhavnoho upravlinnia Ukrainy [Principles of openness and transparency in the activities of public administration of Ukraine]. Extended abstract of candidate's thesis. Kyiv [in Ukrainian].

7. Hudyma, N. (2005). Pryntsypy vidkrytosti i prozorosti ta yikh realizatsiia v derzhavnomu upravlinni [Principles of openness and transparency and their implementation in public administration]. Visn. NADU - Bulletin of the National Academy of Public Administration under the President of Ukraine, 3, 77-85 [in Ukrainian].

8. Hood, Ch. (2006). Transparency in historical perspective. Transparency: The Key to Better Governance. (pp. 3-23). Oxford: Oxford University Press [in English].

9. Afonin, E.A., Sushyi, O.V. (2010). Transparentnist vlady v konteksti yevropeiskoi intehratsii Ukrainy [Transparency of power in the context of European integration of Ukraine]. Kyiv: NADU [in Ukrainian].

10. Romanenko, Ye.O. (2014). Vidkrytist ta prozorist yak strukturni rivni transparentnosti derzhavnoho upravlinnia ta yikh komunikatyvni funktsii [Openness and transparency as structural levels of transparency of public administration and their communicative functions]. Teoretychni ta prykladni pytannia derzhavotvorennia - Theoretical and applied issues of state formation, 14, 17-31 [in Ukrainian]. 
11. Kret, O.V. (2010). Instytualizatsiia transparentnosti derzhavnoi vlady [Institutionalization of transparency of state power]. Extended abstract of candidate's thesis. Chernivtsi [in Ukrainian].

12. Yaroshenko, V.M. (2012). Transparentnist ta vidkrytist vlady yak mekhanizmy stanovlennia instytutu demokratychnoi hromadianskosti [Transparency and openness of power as mechanisms of formation of the institute of democratic citizenship]. Naukovi pratsi Chornomorskoho derzhavnoho universytetu imeni Petra Mohyly. Seriia: Politolohiia - Scientific works of the Black Sea State University named after Petro Mohyla. Series: Political Science, 170(182), 85-91 [in Ukrainian].

13. Pylaieva, V.M. (2016). Pravovi zasady realizatsii pryntsypu transparentnosti v diialnosti orhaniv vykonavchoi vlady [Legal principles of implementation of the principle of transparency in the activities of executive authorities]. Visnyk Kharkivskoho natsionalnoho universytetu imeni $V$. $N$. Karazina. Seriia: Pravo - Bulletin of the VN Karazin Kharkiv National University. Series: Law, 21, 261-264 [in Ukrainian].

14. Gryshchenko, I. (2016). The impact on the formation of personal needs leadership. Scientific Bulletin of National Mining University, 4, 154-160. Retrieved from http://nbuv.gov.ua/UJRN/Nvngu_2016_4_22 [in English].

15. Mosora, L.S. (2018). Vidkrytist yak kryterii otsinky yakosti funktsionuvannia derzhavnoi sluzhby [Openness as a criterion for assessing the quality of the civil service]. Molodyi vchenyi - Young scientist, 1(1), 464-467. Retrieved from http://nbuv.gov.ua/UJRN/molv_2018_1\%281\%29_110 [in Ukrainian]. 